\title{
Le mythe celtique en Irlande : mainstream et underground contemporain. Les exemples d'Enya et de Cruachan
}

The Contemporary Myth of the Celts in Ireland: from (Mainstream) Enya to

(Underground) Cruachan

Frédéric Armao

\section{OpenEdition}

Journals

Édition électronique

URL : https://journals.openedition.org/rfcb/8369

DOI : $10.4000 /$ rfcb.8369

ISSN : 2429-4373

Éditeur

CRECIB - Centre de recherche et d'études en civilisation britannique

Référence électronique

Frédéric Armao, « Le mythe celtique en Irlande : mainstream et underground contemporain. Les exemples d'Enya et de Cruachan », Revue Française de Civilisation Britannique [En ligne], XXVI-3 | 2021, mis en ligne le 14 décembre 2021, consulté le 05 janvier 2022. URL : http://journals.openedition.org/ rfcb/8369; DOI : https://doi.org/10.4000/rfcb.8369

Ce document a été généré automatiquement le 5 janvier 2022.

\section{c) (i) $(9$}

Revue française de civilisation britannique est mis à disposition selon les termes de la licence Creative Commons Attribution - Pas d'Utilisation Commerciale - Pas de Modification 4.0 International. 


\title{
Le mythe celtique en Irlande : mainstream et underground contemporain. Les exemples d'Enya et de Cruachan
}

\author{
The Contemporary Myth of the Celts in Ireland: from (Mainstream) Enya to \\ (Underground) Cruachan
}

Frédéric Armao

\section{Introduction}

1 Les Celtes n'existent pas. L'affirmation, lapidaire, pourrait résumer à elle-seule les conclusions d'une frange des spécialistes du sujet dans la recherche ultracontemporaine. ${ }^{1}$ Plus justement, il est avancé que la notion de « Celtes » modernes et contemporains, c'est-à-dire envisagés comme une émanation et un prolongement d'une tradition multimillénaire dite celtique, n'est qu'une construction artificielle n'entretenant pas - au mieux, peu - de rapport avec une quelconque réalité historique ancienne : les Celtes anciens, si tant est que l'on puisse envisager de regrouper certains peuples sous ce terme chapeau, ne seraient pas les ancêtres de ceux qui réclament, aujourd'hui, une appartenance au monde, à la culture ou à la supposée ethnie celtique.

2 Aujourd'hui plus que jamais, deux théories - presque deux «équipes idéologiques » s'affrontent. Les Celtomanes, minoritaires chez les universitaires, choisissent de croire que l'Irlande, le pays de Galles, l'Ecosse, la Bretagne, l'île de Man et, dans une moindre mesure, la Galice, sont fondamentalement des contrées celtiques : l'adjectif " celtique » s'applique alors non seulement au passé de ces nations et régions mais également à leur présent identitaire, qu'il soit fait référence aux langues, cultures, traditions ou ethnicité possiblement fantasmées. A l'inverse, les Celtosceptiques choisissent la prudence ou, pour un certain nombre d'entre eux, optent pour le révisionnisme 
radical : rien ne serait celte, aujourd'hui plus encore qu'hier; les termes «celte » et "celtique », tel qu'ils sont utilisés, ne seraient d'ailleurs qu'une invention moderne fondée sur des mauvaises interprétations pseudo-historiques. ${ }^{2}$

Depuis au moins le XVIII ${ }^{e}$ siècle, et à plus forte raison la fin du XIX ${ }^{e}$ et le début du XX siècles, la notion de Celtes et de celtisme est effectivement centrale, notamment des points de vue politiques et identitaires : en Irlande, le Gaelic Revival gaélophone et l'Irish Literary Revival anglophone du tournant du $\mathrm{XX}^{\mathrm{e}}$ siècle en ont fait un fer de lance de l'identité nationale, identité alors construite tantôt en opposition binaire au Britannique et à l'Anglais, tantôt glorifiée dans une optique plus œcuménique et fédératrice, avec une volonté de créer une identité panceltique regroupant les différentes nations dites celtiques. En parallèle et dès le XVIII ${ }^{e}$ siècle au moins, la notion de "musique celtique » commença à émerger en Irlande, mais aussi - et peutêtre surtout - aux Etats-Unis. Sans surprise, cette « musique celtique » fut elle-aussi, et probablement dès les origines, fortement associée aux concepts de création et de vecteur d'identité nationale.

4 Cette promotion et cette popularité de la musique dite celtique perdurera tout au long du vingtième siècle et touchera un public de plus en plus vaste, jusqu'à atteindre un palier entre les années 1970 et 1990 . Si la popularité de la musique "celtique » a probablement marqué le pas depuis ces dates dans la culture dite mainstream, il est intéressant de noter une forme de résurgence culturelle dans certains styles de musique dite underground, en Irlande comme ailleurs. Le présent article s'interrogera sur l'utilisation des thématiques propres au celtisme dans ces productions culturelles irlandaises de la fin du XX ${ }^{e}$ et du début du XXI siècles : il prendra comme exemple deux artistes ayant fait grand cas du celtisme dans leurs productions mais appartenant à deux sphères culturelles propres, ayant chacune leurs codes et raisons d'être: la chanteuse Eithne Pádraigín Ní Bhraonáin (anglicisé en Enya Patricia Brennan, dite «Enya »), sortit son premier album «solo » éponyme en 1987, album réédité en 1992 sous le titre de The Celts et qui atteignit alors la première place des ventes en Irlande. Le groupe de Folk Metal nommé Cruachan est quant à lui un fer de lance de la production musicale dite underground en Irlande et, dans une moindre mesure, à l'échelle mondiale; ses albums, aux titres aussi évocateurs que Tuatha na Gael (1995), Folk-Lore (2002) ou Pagan (2004) exploitent à l'envi les thématiques propres au celtisme, depuis la glorification $\mathrm{du}$ passé gaélique de l'Irlande jusqu'aux revendications à l'autodétermination des nations dites celtiques. Il sera ici question de mettre en exergue les différences opposant ces artistes, notamment sous l'angle de la dichotomie underground/mainstream qu'il conviendra de justifier; inversement, on pourra s'interroger sur les similitudes potentielles unissant ces différentes productions culturelles et les inscrire dans une histoire culturelle et identitaire plus large : celle de l'Irlande et des nations dites celtiques.

\section{L'émergence de la musique celtique en Irlande}

D'autres avant nous ont tenté de retracer l'histoire de la musique irlandaise dite gaélique ou celtique à travers les siècles. Quels que soient l'angle retenu et le parti-pris historique - tendant vers la Celtomanie ou le Celtoscepticisme - les chercheurs s'accordent à penser que "la musique celtique contemporaine n'a rien à voir avec les 
musiques jouées à l'époque médiévale dans les cours des chefs de clans et des rois et, a fortiori, en des périodes plus reculées. $»^{3}$

En Irlande, l'histoire de cette musique celtique s'inscrit dans l'Histoire considérée au sens large. Comme pour la culture littéraire ou la langue irlandaises, le tournant majeur de l'histoire de cette musique dite celtique fut la fin du XIXe siècle et le début du XXe siècle : le Renouveau Celtique irlandais fut un pivot dans la création du mythe national irlandais. Ce mouvement intellectuel remit en effet au goût du jour le passé supposément celtique de l'Irlande: alors que certains, notamment Eoin MacNeill et Douglas Hyde - futur premier Président de l'Irlande - privilégiaient l'importance de la langue gaélique comme outil et vecteur identitaire, d'autres préféraient mettre l'accent sur la culture irlandaise ancienne, en l'occurrence les mythes et légendes dits celtiques; ce fut par exemple le cas pour un certain nombre d'écrivains et d'intellectuels protestants, issus de la communauté anglo-irlandaise et ne maîtrisant pas nécessairement la langue gaélique, William Butler Yeats en tête. Si le Gaelic Revival impulsé par MacNeill et Hyde repose avant toute chose sur l'importance de la langue gaélique et son exploitation identitaire, l'Irish Literary Revival de Yeats met donc l'accent sur la culture irlandaise ancienne - dieux et héros celtiques, traditions et folklore gaéliques.

7 Ces idéologies s'inscrivaient dans une mouvance intellectuelle européenne plus large, qui tentait de mettre en avant les similitudes, souvent imaginaires ou reconstruites, unissant les nations dites celtiques: on prend souvent, en France, l'exemple d'Ernest Renan ou, en Angleterre, de Matthew Arnold, qui a notamment créé une chaire d'études celtiques à l'Université d'Oxford. Ces intellectuels, plutôt que de souligner la différence et l'originalité supposées des peuples celtiques en opposition aux « autres », mettaient plus volontiers en avant la notion de panceltisme, comprendre la prétendue unité des nations celtiques. Ce qui se produisit en Irlande fut sensiblement différent : les membres du Gaelic Revival gaélophone, et dans une moindre mesure ceux de l'Irish Literary Revival anglophone, cherchaient à mettre en lumière la construction d'une identité celtico-gaélique en opposition à l'oppresseur anglais et britannique - une idée que l'on retrouve aussi, à l'époque, en France chez les nationalistes bretons, qui construisirent leur idéologie en opposition à la France plutôt que sur les bases d'une identité panceltique fédératrice. ${ }^{4}$

8 D'une manière générale, si le "celtisme » continental s'édifia, au tournant du XIXe et XXe siècle, principalement sur les bases d'un nationalisme inclusif et œcuménique - le panceltisme - la notion se concevait, en Irlande, sur des notions d'opposition et d'exclusion : le gaélique s'opposait à «l'anglo-saxon ». Très tôt, cette idée s'appliqua également à la musique dite celtique, considérée comme partie intégrante de la culture irlandaise. Dans un discours intitulé «The Necessity for De-Anglicising Ireland», Douglas Hyde expliquait :

Our music, too, has become anglicised to an alarming extent. Not only has the national instrument, the harp (...) become extinct, but even the Irish pipes are threatened with the same fate. In the place of pipers and fiddlers, who even twenty years ago, were comparatively common, we are now in many places menaced by the German band ${ }^{5}$ and the barrel organ. For the present, then, I must hope that the revival of our Irish music must go hand in hand with the revival of Irish ideas and Celtic modes of thought which our society is seeking to bring about (...). 6

9 Les premières utilisations $d u$ concept $d u$ «musique celtique » (au sens moderne $d u$ terme) dans le cadre de la construction identitaire irlandaise s'inscrivirent dans les 
mouvances politiques mentionnées précédemment, mouvances étant elles-mêmes le produit du Romantisme des XVIIIe et XIXe siècles. Les premières références à la «musique celtique » aux Etats-Unis apparurent d'ailleurs dès les années 1880. Cette utilisation s'inscrivait dans le contexte du Renouveau celtique et de l'opposition à l'anglais, ce qui n'est pas étonnant lorsque l'on connait l'importance de la diaspora irlandaise aux Etats-Unis, en l'occurrence au nord-est du pays et à la fin du XIXe siècle :

[These references] demonstrate a tendency toward binary opposition, as part of an effort to advertise 'Celtic' traditional music as an aspect of Irish cultural distinctiveness from the English other. In addition, musical 'Celtomania' in Chicago was most likely a transatlantic product of the nationalist Gaelic revival driven by the Conradh na Gaeilge (Gaelic League), and the Celtic revival, initiated by Ireland's Anglo-Irish ascendant literati, though Chicago musicians made no specific references to William Butler Years or Lady Augusta Gregory. ${ }^{7}$

10 L'histoire de la musique dite celtique est, en effet, indissociable de l'histoire de la diaspora irlandaise aux Etats-Unis. Erick Falc'her-Poyroux rappelle que Francis O'Neill, le "principal artisan du renouveau de la musique irlandaise au XXe siècle fut un Irlandais originaire du comté de Cork [arrivé] à New York à l'âge de 18 ans » et installé définitivement à Chicago en 1871, à une époque où 40000 irlandais y résidaient, soit 13\% de la diaspora irlandaise aux Etats-Unis. ${ }^{8}$ Soutenu par la Gaelic League, Francis O'Neill chercha à rassembler le plus grand nombre de mélodies irlandaises « auprès de ses amis et collègues à Chicago et les publications qu'il en fit au début du XXe siècle forment aujourd'hui encore la base du répertoire de la majorité des musiciens irlandais dans le monde $» .^{9}$ De fait, il est intéressant de constater que, dès cette époque, la musique irlandaise dite traditionnelle était régulièrement désignée par le terme de "musique celtique ${ }^{10}$ Parler de «musique celtique » aux Etats-Unis, au tournant des XIXe et XXe siècles, semble en fait avoir été un raccourci commode. C'était aussi, et peut-être surtout, une démarche particulariste axée sur l'exclusion, le rejet de «l'autre », de "l'anglo-saxon» et la consolidation des identités irlandaises et américano-irlandaises - un geste authentiquement politique, en somme.

11 Aux Etats-Unis, l'utilisation de l'adjectif «Celtic» en relation avec la musique et le monde de l'entertainment se poursuivit tout au long du XXe siècle. ${ }^{11}$ Mais c'est au cours des années 1970-1990 que le concept de "musique celtique » fut le plus volontiers exploité par certaines maisons de disques, des deux côtés de l'Atlantique. Loin de se faire l'écho de velléités nationalistes, la mise en avant du « celtisme » musical doit alors se comprendre comme une volonté d'exploiter un filon commercial. Cette exploitation du celtisme fut rendu d'autant plus efficace que le terme "celtique " était particulièrement lisible pour une certaine frange des consommateurs, en l'occurrence les descendants d'immigrants irlandais ou écossais, très prompts à se reconnaitre dans cet adjectif fourre-tout, ce "sac magique» pour reprendre l'expression de J.R.R. Tolkien..$^{12}$ Paradoxalement, c'est parce qu'il est imprécis, généralisant, nébuleux, que l'adjectif «celtique » permet de renvoyer, à moindre frais, à une identité imaginée et fantasmée: dans le dernier quart du XXe siècle, le «celte» devient bel et bien mainstream.

\section{Enya ou le celtique mainstream}

12 En France, le pionnier de ce renouveau «celtique » que le grand public choisit de plébisciter fut sans conteste Alan Stivell: le titre de son troisième album studio 
enregistré en 1971, Renaissance de la harpe celtique, est éloquent et nous informe sur la démarche artistique et identitaire poursuivie. Le succès commercial de Stivell a pu fluctuer au fil des décennies, notamment ces vingt dernières années: pourtant, ses productions, pour certaines plusieurs fois « disque d'or » dans les années 1970 et 1990, atteignent encore régulièrement des places honorables dans le top 100 des ventes d'album en France. ${ }^{13}$ De fait, il est possible d'identifier Stivell comme un acteur de la culture mainstream - terme qu'il convient au demeurant de définir.

La notion de mainstream renverra, dans ces quelques pages, à l'aspect "accessible", grand public, sinon ouvertement commercial des productions y étant rattachées: l'appartenance au mainstream se comprend avant toute chose comme une volonté établie de l'artiste - et/ou de ses producteurs - de diffuser ses productions au plus grand nombre et de les promouvoir par le prisme des médias de masse. Les grands acteurs de la scène mainstream se doivent de rencontrer un public large, si possible à l'international. On le comprend, le mainstream sera volontiers opposé à la notion d'underground, si clairement définie par Philippe Birgy dans le présent ouvrage. Pour reprendre les fameux termes prêtés à Frank Zappa et cités par M. Birgy : "The mainstream comes to you, but you go to the underground ». ${ }^{14}$

14 En Irlande, la «musique celtique » sera tout d'abord portée par un certain nombre de groupes de Rock celtique, en premier lieu Horslips et Thin Lizzy qui, dès l'aube des années 1970, choisirent d'intégrer à leurs productions musicales des instruments dits traditionnels (cornemuse, violon, flute, harpe...), de reprendre et réinterpréter des airs tout autant traditionnels ${ }^{15}$ d'élaborer des paroles en langues dites celtiques (irlandais, voire manxois pour Horslips) ou traitant de thématiques relatives à la mythologie irlandaise ancienne, par exemple.

15 Si le succès d'Horslips, groupe aujourd'hui considéré comme précurseur, fut limité - il disparut dès le début des années 1980 - les Dublinois de Thin Lizzy rencontrèrent leur public : à titre d'exemples, leur reprise de la chanson traditionnelle Whiskey in the Jar fut un succès international et compte aujourd'hui plus de 10 millions de vues sur YouTube ; le morceau The Boys are Back in Town atteignit, lui aussi, les sommets des charts occidentaux. Pourtant, leur assimilation avec la mouvance Hard Rock, voire Heavy Metal, place le groupe dans une sorte d'entre-deux, ni complètement mainstream ni réellement underground. Il faudra attendre la création du groupe Clannad et, plus encore, la carrière «solo » entreprise par l'un de ses membres, Enya, pour réellement confirmer l'émergence mainstream de la musique irlandaise dite celtique. On peut d'ailleurs décemment s'interroger sur la classification en "musique celtique ", pourtant récurrente, des productions artistiques d'Enya, qui semble plus proches, dans le plupart des cas, de la World Music que de la musique irlandaise traditionnelle.

Eithne Pádraigín Ní Bhraonáin fut tout d'abord un membre éphémère du groupe familial Clannad; après deux années passées au sein de la formation, Enya laissa ses frères et sœurs à leur succès et entama une carrière solo. Dans un entretien donné en 1987, Enya revient sur le début de sa carrière et confirme son attachement à ses racines, et en l'occurrence à sa langue natale, l'irlandais :

I come from an area called Gaoth Dobhair, which is in the northwest of Donegal. It's the area where we only speak Irish. It's the Gaeltacht part. And my family come from here and they've got a very strong musical background. My father and my mother were both in a show band called the Slieve Foy Dance Band. They used to tour a lot in Ireland, and in England, and in Scotland. Being brought up in the Gaeltacht, you're brought up speaking Irish, so you go to school to learn how to 
speak English. There's a very strong traditional background in the Gaeltacht and it appealed to me. And then, later on, when I went to boarding school and started studying classical music I combined the two. When I was with the group Clannad, who are my immediate family, I was touring with them for two years. I was playing keyboards, synthesizers, and Wurlitzer piano. And from there on I used the piano as my main instrument, but a lot of the synthesizer as well. ${ }^{16}$

Son premier album éponyme sortit en 1987 et fut reédité quelques années plus tard, en 1992, sous le titre de The Celts. Il rencontra un certain succès, atteignant la $29^{\mathrm{e}}$ place des classements au Royaume-Uni. ${ }^{17}$ Cette œuvre était en fait un travail de commande, destiné à faire office de bande-son à un documentaire de la BBC sur l'histoire des Celtes. 18

Pourtant, l'écoute de l'album interroge : The Celts ne ressemble pas, à proprement parler, à de la "musique celtique » contemporaine telle qu'on peut se la figurer ; les tonalités et les modes n'évoquent pas ceux utilisés dans le style musical généralement qualifié d'« irlandais » ou de "celtique », ${ }^{19}$ à l'exception notable de trois morceaux sur les seize que compte l'album $;^{20}$ dans l'écrasante majorité des cas, les instruments utilisés sont des synthétiseurs, bien plus rarement des instruments traditionnels, même si l'on note la cornemuse du morceau The Sun in the Stream et la présence ponctuelle d'un violon ; les chants, très doux et aériens, évoquent avant toute chose la World Music ou le New Age, styles couramment associés à des pratiques de relaxation ou de méditation. Si la langue choisie est le plus souvent l'irlandais, la vacuité des paroles laisse songeur, comme par exemple pour le premier morceau, intitulé The Celts :

Hi-ri, Hi-ro, Hi-ri.

Hoireann is $O$, ha hi, ra ha, ra ho ra.

Hoireann is $\mathrm{O}$, ha hi, ra ha, ra ha ra.

Hi-ri, Hi-ra, Hi-ri.

Saol na saol,

Tús go deireadh.

Tá muid beo

Go deo. ${ }^{21}$

19 Si l'on exclut les onomatopées, cet extrait pourrait se traduire par « La vie des vies, le début de la fin, nous sommes vivants, pour toujours » : comme souvent dans la World Music, les paroles servent de prétexte ou si l'on veut, de support à la mélodie ; on pourrait de fait considérer le support textuel comme quasi-litanique - voire performatif, une partie intégrante de la création musicale. Pour un autre morceau, Enya semble avoir été inspirée par ce qu'elle estime être des traditions celtiques anciennes. La chanteuse ne fait pas mystère d'une certaine appétence pour ces thématiques :

There's a piece that I wrote called 'Deireadh an Tuath', which means "The End of the Tribe", or "The End of an Clann". And when I was reading about the Celts, I was reading about their beliefs in, in a lot of things like the magic of the sun, and the magic of the moon. And, um, the actual piece, the words in it are like " sí, sí an ghealach, mall san oíche". It means "the magic of the moon, stay with us". And, um, it ends off saying that all these beliefs in the magic is sort of dying. ${ }^{22}$

Les paroles du morceau en question pourraient se traduire comme suit : " C'est la Lune, tard dans la nuit, c'est le Soleil, reste avec moi pour toujours. Hoireann is O Hi O Ho ra Ha. C'est Samhain, ${ }^{23}$, c'est un arbre mort, fin de la tribu $»{ }^{24}$ On ne se prononcera pas ici sur la pertinence et l'authenticité de ces extraits supposés faire écho à des traditions celtiques anciennes. ${ }^{25} \mathrm{Il}$ est néanmoins possible de constater que l'inspiration celtique, 
si elle ne se ressent pas nécessairement dans la musique, a donc joué un certain rôle dans la composition et l'écriture du morceau en question.

Pourtant, il apparait très clairement que l'estampille "celtique ", appliquée à Enya, semble une nouvelle fois être un raccourci commode et vendeur : le « celtique » est luiaussi un prétexte, un support vendeur qui trouve son origine dans le fait que la chanteuse-compositrice est irlandaise, en l'occurrence issue d'un Gaeltacht, zone où l'irlandais est langue maternelle. Pour sa maison de disque, ce fait justifiait à lui seul l'assimilation d'Enya - qui avait pourtant choisi d'angliciser son nom dès le début de sa carrière - à la culture celtique. Nous rejoignons bien la remarque de Michael D. Nicholsen, lorsqu'il affirme :

(...) late twentieth-century labels and 'Celtic' enthusiasts applied the term to any music produced by anyone whose identity could be constructed as 'Celtic' (i.e. people from a 'Celtic' nation or whose music was somehow inspired by the same). Record moguls ensured that 'New Age' songstresses such as Ireland's Eithne Ní Bhraonáin, better known as Enya, Canada's Loreena McKennitt, and acts like Clannad, Anúna, and Jeff Johnson and Brian Dunning had their recordings filed under 'Celtic' along with traditional musicians. ${ }^{26}$

Loin d'être un cri politique ou une affirmation identitaire, la catégorisation de certains acteurs de la World Music et du New Age à la mouvance "Celtic Music $"{ }^{27}$ semble donc, dans le cas d'Enya comme dans la plupart des grands protagonistes du mainstream, une construction a posteriori, destinée à promouvoir les artistes et assurer une meilleure visibilité sur les marchés internationaux. La facilité d'accès de cette musique calme et relaxante, émaillée de tonalités ou de références au «celtique " ponctuelles, lui a permis de toucher un public large et de dégager des bénéfices confortables : avec plus de 75 millions d'albums vendus en $2015,{ }^{28}$ Enya est l'artiste irlandaise « solo » la plus vendeuse de tous les temps ; ${ }^{29}$ The Independent la désigna, en 2016, comme l'artiste féminine la plus riche de son pays, en dépit du fait qu'elle ne se produise que très rarement en public..$^{30}$ Enya et sa "musique celtique » sont de véritables acteurs d'une culture mainstream fédératrice, qu'on les considère du point de vue de la forme (une musique lisse et accessible, assez typique de la mouvance World Music) ou du fond (l'absence de revendication politique ou de message réel susceptible de heurter et rebuter telle ou telle fraction de son auditoire, ce qui est également tout à fait représentatif de l'innocuité lyrique de la plupart des grands représentants de la World Music). A ce titre également, on peut l'opposer de manière presque frontale à certains acteurs de la scène musicale irlandaise dite underground et revendiquant, eux aussi, une appartenance à cette « musique celtique », décidément protéiforme entre toutes.

\section{Cruachan ou le celtique underground}

Il est possible de retrouver des éléments de musique dite celtique dans un certain nombre de styles associés à la scène underground ultracontemporaine: le plus représentatif d'entre eux est probablement le Folk Metal, style apparu dans les années 1990 qui, comme son nom l'indique, se veut être une fusion de Heavy Metal - ou de l'un de ses sous-genres - avec de la musique dite traditionnelle. Il existe donc, par définition, des groupes de Folk Metal intégrant des musiques traditionnelles issues de divers pays et de diverses cultures: les groupes inspirés par la culture scandinave se revendiqueront par exemple du sous-genre de Folk Metal nommé Viking Metal (comme les Suédois du groupe Bathory ou les Norvégiens d'Enslaved), ${ }^{31}$ ceux préférant les 
sonorités Moyen-Orientales seront classés dans la catégorie Oriental Metal (Orphaned Land, Melechesh...), ${ }^{32}$ pour ne citer que deux des exemples les plus représentatifs. Le pionnier du genre Folk Metal fut le groupe britannique de Skyclad, suivi de près par les Irlandais de Cruachan. Dans un entretien donné en 2006, Keith Fay, fondateur et principale force créatrice derrière Cruachan proposait sa version de l'historique du Folk Metal :

I think Cruachan and Skyclad are the first folk metal bands. I think Skyclad are instantly regarded as being the founders of folk metal. (...) During the nineties and even at the end of the nineties, there were very few bands. We had Waylander from Ireland. And one or two in Europe, but it was very rare to get a real folk metal band. Nowadays it is a bit of an explosion all over the place. (...)

Many people regarded folk metal as funny, but the roots of heavy metal come from folk music. And that is the truth. If you look at the earliest metal bands, like Black Sabbath, Deep Purple, Thin Lizzy, Iron Maiden,... listen to their music, a lot of the structures in the songs, a lot of the melodies they are playing, if you replace the electric guitar with a fiddle or a flute, it is folk music..$^{33}$

Plus encore qu'une appartenance au Folk Metal, Keith Fay revendique l'affiliation avec un sous-genre du Folk Metal, à savoir le Celtic Metal - puisque le folklore en question est supposé être originellement celtique. Il s'inscrit, de fait, dans la continuité du Rock celtique des années 1970, au point de déclarer, en 2002, que «The [sic] Horslips have been a huge influence on Cruachan, what they were doing in the 70's is the equivalent of what we do now $»{ }^{34}$ Fay se revendiquant aussi des affinités avec la mouvance néo-païenne, ${ }^{35}$ l'étiquette de Pagan Metal est parfois utilisée par la presse spécialisée pour classifier le style de Cruachan.

La musique du groupe intègre donc des instruments irlandais dits traditionnels ${ }^{36}$ aux sonorités rugueuses de la musique Metal, dont la définition simple et généralisante proposée par Mayer et Timberlake en 2014 suffira à la présente discussion :

Occasionally borrowing from jazz and classical music, contemporary metal music typically uses highly distorted guitars, rapid-fire "blast beat" drumming, complex time signatures, flamboyant instrumental virtuosity, and atonal or dissonant arrangements that are unappealing to many listeners. Metal vocalists eschew singing techniques more common in pop music, frequently growling or screaming, thereby rendering the lyrics unintelligible..$^{37}$

Sur la majorité de ses albums, Cruachan superpose aux chants «inintelligibles » et rauques propres au Metal underground une voix féminine claire et parfaitement compréhensible, capable donc de véhiculer des messages sans que l'on ait besoin d'avoir recours à des transcriptions de paroles.

27 A en croire le fondateur du groupe, le concept de Cruachan s'impose comme une évidence dès le départ :

(...) the concept of Cruachan is to tell tales of Celtic and Irish history. We hope that we will inspire our fans to learn about the history in their own country. In these modern, technological times, people are more and more forgetting their culture and heritage and it saddens me a lot. (...) The word "folk" means people and "lore" is their history and that is essentially what Cruachan sing about, the history of the people. ${ }^{38}$

From day one, from the days of the 'Celtica' demo and 'Tuatha Na Gael', the main concept of Cruachan was to sing about Irish mythology and Irish history. We always took the really ancient history, the Celtic times of Irish history and the Gael and stuff like that. ${ }^{39}$ 

l'intérêt entretenu par ses membres vis-à-vis de cette fameuse "culture celtique ». Le nom même de Cruachan renvoie au fort de Rathcrogan (en irlandais, Ráth Cruachan), dans le comté de Roscommon, site archéologique ayant une place de choix dans l'histoire ancienne et la mythologie irlandaise, et parfois identifié comme l'un des points de passages entre le monde des morts et celui des vivants. ${ }^{40} \mathrm{La}$ première maquette du groupe, intitulée Celtica, leurs albums Tuatha na Gael (1995), Folk-Lore (2000), Pagan (2004), The Morrigan's Call (2006), ${ }^{41}$ les compilations nommées respectivement A Celtic Trilogy (2002) et A Celtic Legacy (2007), sans même mentionner les très nombreux noms de morceaux rappelant la mythologie celtique irlandaise ${ }^{42}$ témoignent bien d'un goût prononcé pour le passé préchrétien de l'Irlande.

Souvent, les paroles en question reprennent et adaptent les grands mythes et légendes celtiques retranscrits dès le haut Moyen Age dans les monastères irlandais : rappelons que les Celtes insulaires ne couchaient pas leur savoir par écrit et que la plupart de ces mythes et légendes celtiques sont connus grâce au travail précieux des moines irlandais, qui ont cherché à transcrire les traditions ayant précédé l'arrivée du Christianisme en Irlande. Des vagues de transcripteurs se succédèrent. S'inspirant des écrits les ayant précédés, chacun des transcripteurs adapta les mythes et légendes, tantôt en modifiant certains détails, tantôt en ajoutant des épisodes inédits, tantôt en supprimant des éléments jugés inutiles ou inopportuns ; de fait, les mythes dits celtiques sont devenus, au fil des siècles, une matière vivante, fluctuante, qui ne peut pas être dissociée de ses "passeurs». On comprend rapidement, à la lecture de certaines paroles de Cruachan, que le groupe s'inscrit, volontairement ou non, dans cette tradition des "passeurs de mythes" irlandais: les épisodes mentionnés s'inspirent visiblement des mythes irlandais anciens tels qu'ils ont été retranscrits au fil des siècles, et les auteurs y ajoutent une touche personnelle, symptomatique de leur vision contemporaine. ${ }^{43}$

Mais la rhétorique de Cruachan ne se limite pas à la transmission «adaptée " des mythes irlandais anciens : par paraphraser Fay, le concept du groupe est bien de relater des " tales of Celtic and Irish history ", de chanter la mythologie irlandaise mais aussi son histoire, dans une perspective presque éducative ${ }^{44}$ et identitaire, sur fond d'engagement politique.

Les membres de Cruachan revendiquent leur fierté d'être Irlandais, ${ }^{45}$ tout en se démarquant des nationalismes extrémistes : l'imagerie celtique a pu être récupérée par une frange de l'underground contemporain pour être associée à l'idéologie néo-nazie, ce que dénonce très ouvertement le leader du groupe. ${ }^{46}$ Pourtant, lorsque la notion de nationalisme est comprise dans le cadre des relations britannico-irlandaise, la réponse apportée par Fay est radicale :

I don't mean to sound arrogant or anything but what we sing about actually happened and is part of our history like our song 'Bloody Sunday' from 'Folk-Lore', even U2 have a song about this tragic day. We're in no way anti-English and whatever happened in the past is history. Some good friends of mine are English and I'd hate to think of people thinking that Cruachan are anti-English. I know we may get trouble from people who aren't clued in to what the band are about and may even call us racist which some people have called us before because we sing about our own culture, but these people just need to be educated in history and politics. ${ }^{47}$ 
Se dédouaner de toutes velléités xénophobes ou nationalistes en arguant qu'on «a de bons amis » anglais n'est évidemment pas un argument valable ou suffisant. En outre, dans les entretiens donnés par Fay, certaines comparaisons historiques interrogent : «I hear on the news about the uncivilised Talibaan [sic], I wonder what the people of England think about their army killing innocent people in their name. ${ }^{48}$ Pourtant, s'il est clair que les paroles sont engagées dans une optique nationaliste, construite en opposition à celui qui est présenté comme l'oppresseur britannique, le propos de Cruachan ne verse jamais dans l'appel à la haine. Véritable cri du cœur, les paroles du Bloody Sunday de Cruachan sont l'expression d'une indignation viscérale mais aussi, en creux, d'une volonté de légitimer les revendications nationalistes. On remarquera au passage que les Dublinois de Cruachan écrivent leurs paroles en anglais, et non en gaélique :

Remember well the 30th of January, (...)

13 people lost their lives that Sunday,

Women, children and innocent men.

Many wounded lay crying in agony,

The knights of Malta attended them.

And so began the government cover up.

And so began the lies and deceit.

Soldiers statement would be changed and torn up,

No reports would come from men on the street.

As the years went by the people began to talk,

The hidden crimes were now being told.

Innocent protesters - shot in the back,

Left to die in the winter cold.

The bullets used had all been tampered,

Maximum injury would come from them.

This tyranny will not go un-noticed,

Our day will come again. ${ }^{49}$

Un exemple similaire se retrouve dans le morceau intitulé " Michael Collins ", ${ }^{50}$ sur l'album Pagan. La mort du révolutionnaire irlandais y est présentée d'une manière très partisane, typique de l'approche nationaliste ${ }^{51}$ qui tend à verser dans l'hagiographie et oppose généralement Collins à De Valera. ${ }^{52}$ La rhétorique du morceau «Michael Collins» est principalement descriptive; les quelques envolées lyriques, qui n'échappent pas aux poncifs du genre, dénotent une certaine candeur et ne permettent pas à Cruachan de rivaliser avec les grands poètes et artistes irlandais les ayant précédés. ${ }^{53}$

Le dernier cheval de bataille de Cruachan prend, cette fois, la forme de la confrontation ouverte : le groupe prend résolument partie contre le Christianisme et, d'une manière plus générale, la religion institutionnalisée. Cette prise de position n'est pas surprenante de la part d'un groupe se revendiquant du néopaganisme et s'inscrivant dans la mouvance plus large du Metal underground: certaines franges de ce Metal underground ont depuis longtemps fait de l'antichristianisme un de leurs grands axes idéologiques. ${ }^{54}$ Mais cette lutte contre les religions ${ }^{55}$ doit aussi s'interpréter à la lumière des différents scandales ayant éclaboussé l'Eglise Catholique d'Irlande depuis les années 1990 et ayant laissé une trace profonde dans les esprits. Ainsi, les paroles du morceau éponyme de l'album Pagan, sorti en 2004, combinent une rhétorique antichrétienne acerbe et circonstanciée $e^{56}$ - tout à fait typique des mouvances du Metal underground contemporain - à des considérations plus ancrées dans l'actualité irlandaise des années 90 et 2000 :

Revue Française de Civilisation Britannique, XXVI-3 | 2021 
A scourge on the world from the earliest days

Christ, his church and his sinister ways

Starter of wars, Instigator of crimes

Despoiler of cultures, Destroyer of minds

More people have died in the name of Christ

Than any other in the history of life

You kill all who oppose your perfidious might

A religion of conquest born in black light

Our father who art in heaven

Corruption be thy name

You blind your people with lies

False prophet your only gain

Thy kingdom come and be done

Your time is now at an end

The veil is slowly being lifted

Your past you must try to defend [bis]

They prey on our children so young and naive

These pedophile bastards they are a disease

They preach about love, or so I am told

But the love that they practice is twisted and cold. ${ }^{57}$

$\mathrm{Au}$ regard de ces paroles pour le moins engagées et peu "radio-friendly", on comprend que le succès commercial de Cruachan ne soit pas au rendez-vous - sans même parler de la musique en tant que telle, difficile d'accès du fait de ses sonorités rugueuses, typiques de la mouvance Metal, et de sa violence relative, en dépit de l'utilisation d'instruments dits traditionnels. Les entretiens donnés par Kay au fil des années confirment que les revenus furent et demeurent une source d'inquiétude et de conflit au sein du groupe, à des années-lumière du triomphe d'Enya, comme on pouvait s'y attendre. L'argent est, selon les dires de Kay, leur talon d'Achille $:^{58}$ les membres de Cruachan ont tous, en parallèle à leur carrière de musicien, un travail "alimentaire " leur prenant beaucoup de temps et ne leur permettant pas d'affiner leurs connaissances musicales, par exemple en approfondissant leurs connaissances théoriques et pratiques de la musique traditionnelle..$^{59}$ En outre, et comme souvent dans le milieu underground, les labels et maisons de disque ne semblent pas prêts à investir suffisamment dans la production de leurs albums; cela est d'autant plus le cas pour Cruachan, dont l'utilisation d'instruments dits traditionnels complexifie énormément le processus d'enregistrement :

The reason we didn't record [in Sun Studios, Dublin] was because it got too expensive for our label to fund which is the bane of many bands and so we had to look for a cheaper studio. (...) Personally I'm not happy but it was due to time and money restrictions. (...)We're not like an average metal band consisting of 3 different guitars, a drum kit and a singer, we have a much more complex situation and need more time to get everything together so that it sounds ok. ${ }^{60}$

Loin de travailler avec des grandes maisons de disque mainstream, Cruachan s'est engagé, tout au long de sa carrière, avec de petits labels indépendants, parfois obscurs, qui ont pu profiter de la situation : non-paiement de royalties - en dépit de "milliers et de milliers d'albums vendus " ${ }^{-61}$ ou refus de régler les studios d'enregistrement, au point de laisser une ardoise de 12000 euros aux membres de Cruachan $^{62}$ et de mettre en jeu la pérennité du groupe.

Oh, I must admit, to be honest with you, I came very close to stop with it. I have a family, I got children and music has to be something positive, but they saw me 
worried and stressful and been taken to court. It made me think 'this is just not worth it'. ${ }^{63}$ difficultés financières et, par voie de conséquence, artistiques et humaines semblent bien être l'apanage de la plupart des acteurs de cette scène. Toutefois, on comprend bien que, dans le cas de Cruachan, il s'agit moins d'un choix délibéré, identitaire voire "de principe ", que d'un corollaire malheureux à leurs préférences artistiques: les membres de Cruachan produisent du Celtic Metal, et ce style musical, peu accessible, n'interpelle pas les masses; puisque les producteurs savent que les bénéfices ne seront pas au rendez-vous, les albums sont en général mal financés, ce qui éloigne encore plus le grand public, habitué à des sonorités lisses et bien maîtrisées. On imagine bien les difficultés à s'échapper de ce qui ressemble moins à un cercle vicieux qu'à une « Downward Spiral » inhérente à l'underground.

\section{Conclusion}

Les différences opposant les «musiques celtiques» mainstream et underground sont frappantes et il semble bien, en fin de compte, que tout les oppose, sur le fond comme sur la forme : la gaélophone Enya écrit souvent en irlandais mais ses textes ne sont porteur d'aucune revendication et donne une impression générale d'innocuité ; les Dublinois de Cruachan écrivent en anglais mais se font les avocats d'un retour aux sources, d'une quête d'identité - plus ou moins imaginaire. De ce point de vue, le groupe n'est pas sans rappeler les mouvances irlando-américaines des XIXe et XXe siècles, véritables architectes de l'identité irlandaise renouvelée et construite en opposition à l'Anglais : souvent, la radicalité vient de l'extérieur et les Dublinois de Cruachan, anglophones, sont eux-aussi extérieurs au monde gaélique idéalisé, rural, ancien, dont ils se font les apôtres. Enya, qui vient du Donegal et qui parle irlandais, ne se sent pas obligée de revendiquer son appartenance au monde celtique, de nécessairement utiliser des instruments dits traditionnels ou de politiser son discours. Sa musique est facile d'accès et semble avoir pour objectif le beau, voire le sublime - on pourrait arguer que les nappes de synthétiseurs, souvent qualifiées par les critiques d'« aériennes ", et les lignes de chant douces et éthérées invitent à la relaxation et la transcendance, un des buts avoués de la World Music. De fait, Enya exploite bien, volontairement ou non, le caractère Romantique, au sens premier du terme, du monde celtique tel qu'il est généralement perçu par les masses. Inversement, les rythmiques frénétiques de Cruachan, ses sonorités âpres, son chant rauque et ses paroles subversives sont aux antipodes de cette vision néoromantique : le groupe construit son identité celtique sur l'expression d'une révolte, sur la rébellion face à l'oppresseur «non-celte »- qu'il s'agisse du Chrétien ou de l'Anglais. De fait, si le mainstream d'Enya offre une vision romantique du "celte ", l'underground de Cruachan revêt l'armure du rebelle gaélique. Ce diptyque romantisme/rébellion de l'identité irlandaise renouvelée par le celtisme n'est d'ailleurs pas une nouveauté : Enya et Cruachan sont en fait les avatars ultracontemporains du «celte » réinventé au tournant des XIXe et XXe siècle par les acteurs du Renouveau Celtique - le Gaelic Revival gaélophone d'une part et l'Irish Literary Revival anglophone de l'autre. Sans aller jusqu'à affirmer qu'Enya s'inscrit dans la tradition ouverte par le Gaelic Revival, peut-être plus influencé par le Romantisme, et que Cruachan suit la voie tracée par l'Irish Literary Revival dublinois, mettant l'accent sur la culture gaélique fantasmée plus encore que sur la langue, ${ }^{64}$ on comprend toutefois la

Revue Française de Civilisation Britannique, XXVI-3 | 2021 
richesse et la polysémie du terme «celtique ». De la même manière que le Renouveau Celtique ne peut se comprendre sans envisager à la fois le Gaelic Revival et l'Irish Literary Revival, la musique celtique contemporaine doit se concevoir par le prisme du mainstream et de l'underground: ses représentants ne s'opposent que parce qu'ils sont les deux faces d'une seule et même pièce imaginaire, à la valeur artistique nécessairement relative mais précieuse entre toutes, des points de vue historiques et culturels.

\section{BIBLIOGRAPHIE}

ARMAO, Frédéric, «Fête et Celtisme ou la forge identitaire » in Les Nations Celtiques et le monde contemporain, Babel-Civilisations \& Sociétés, Université de Toulon, nVIII, 2013, 203-19.

BROWN, A.R. « Heavy Genealogy: mapping the currents, contraflows and conflicts of the emergent field of metal studies, 1978-2010 » in Journal for Cultural Research, vol. 15 (3), p. 213-242.

BRUNAUX, Jean-Louis, Les Celtes. Histoire d'un Mythe. Paris, Belin, 2014.

CHARTIER, Erwan, La construction de l'interceltisme en Bretagne, thèse de doctorat, 2010.

DowLING Martin, Traditional Music and Irish Society: Historical Perspectives, New York, Routledge, 2015.

FALC'HER-POYRoux, Erick, « Celtic music » in Music around the World - A Global Encyclopedia, ABC-Clio, 2020.

FALC'HER-POYROUX, Erick, Histoire sociale de la musique irlandaise: Du Dagda au DADGAD, Oxford, New York, Vienne, Peter Lang. Édition Kindle.

FALC'HER-POYROUX, Erick, « L'Interceltisme musical : genèse d'une naissance » in ARMAO, Frédéric (ed.), Les Nations Celtiques et le monde contemporain, Babel-Civilisations \& Sociétés, Université de Toulon, $\mathrm{n}^{\circ}$ VIII, 2013, 133-152.

GRAHAM Stephen, Sounds of the Underground: A Cultural, Political and Aesthetic Mapping of Underground and Fringe Music, Ann Arbor, MI, University of Michigan Press, 2016

HYDE Douglas, « The Necessity for De-Anglicizing Ireland » (1892) in O CONAIRE BreandAn (ed.), HYDE Douglas: Language, Lore, and Lyrics, Dublin: Irish Academic press, 1986.

LE ROUX, Françoise et GUYONVARC'H, Christian-Jacques, Les Druides, 4 édition, Rennes, Ouest-France, 1986.

MACKILLOP, James, Dictionary of Celtic Mythology, Oxford, Oxford University Press, 1998

MARKWICK, Marion, « Marketing Myths and the Cultural Commodification of Ireland », in

Geography, vol. 86 (1), 2001, 37-49.

MAYER Adam \& TIMBERLAKe Jeffrey M., " 'The Fist in the Face of God': Heavy Metal Music and Decentralized Cultural Diffusion » in Sociological Perspectives, Vol. 57, No. 1 (printemps 2014), Sage Publications, Inc., p. 27-51. 
NICHOLSEN, Michael D. « 'File under Celtic': The Uses and Misuses of a Musical Myth, 1882-1999 » in Canadian Journal of Irish Studies, n², 2016, p. 135-161.

SOMMERS SMITH, Sally K. « Irish Traditional Music in a Modern World » in New Hibernia Review / Irish, vol. 5, n², 2001, p. 111-125.

TOLKIEN, John Ronald Reuel, « English and Welsh », inaugural O’Donnell Memorial Lecture at the University of Oxford, 21 octobre 1955, 185-6, in TOLKIEN, J.R.R. \& Christopher (ed.). The Monsters and the Critics, and Other Essays, George Allen \& Unwin, Londres, 1983 : 162-197.

\section{Webographie}

Tous les sites mentionnés dans cet article ont été visités pour la dernière fois le 24 février 2021.

\section{Entretiens}

\section{Cruachan 2002}

https://web.archive.org/web/20120210150222/http://www.rock-impressions.com/ cruachan_inter1e.htm

\section{Cruachan 2004}

https://web.archive.org/web/20080304065301/http://www.getreadytorock.com:80/pure_metal/ cruachan.htm

\section{Cruachan 2006}

https://archive.vn/20120805010403/http://www.lordsofmetal.nl/showinterview.php? id=1544\&lang=en

Enya

http://enyabookofdays.com/articles/wm-tv01.htm

\section{Paroles}

https://www.allthelyrics.com/lyrics/cruachan/bloody_sunday-lyrics-534227.html https://www.allthelyrics.com/lyrics/cruachan/michael_collins-lyrics-534236.html https://genius.com/Cruachan-pagan-lyrics https://www.lyrics.com/lyric/2067923/Enya/Celts https://www.lyrics.com/lyric/2775787/Enya/Deireadh+an+Tuath https://www.musixmatch.com/lyrics/Cruachan/Cuculainn

\section{Charts}

https://lescharts.com/showitem.asp?interpret=Alan+Stivell\&titel=Amzer\&cat=a https://www.officialcharts.com/artist/29512/enya/

\section{Enya}

https://www.bbc.com/news/entertainment-arts-34614590 
https://www.imdb.com/title/tt0271900/

https://www.npr.org/templates/story/story.php?storyId=99190609\&t=1611322256797

https://www.independent.ie/entertainment/music/music-news/enya-irelands-wealthiestfemale-performer-despite-not-touring-as-u2-ranked-third-in-music-millionaires-top-50list-34646726.html

\section{Autres ressources citées}

https://www.billboard.com/music/afrocelts/chart-history/WLP

https://www.youtube.com/watch?v=2Wmf1xmkuxo\&ab_channel=EarthRitual

\section{NOTES}

1. Voir notamment les travaux de Jean-Louis Brunaux, par exemple celui détaillé dans la note suivante.

2. Sans entrer dans un détail inutile à notre propos ni verser dans une longue litanie de noms accompagnés de leur affiliation à tel ou tel école de pensée, on notera que les écrits de Jean Markale sont probablement ceux qui ont reçu le plus d'écho - à défaut d'être les plus sérieux et crédibles - parmi la communauté des «Celtomanes » alors que Jean-Louis Brunaux est sans doute le représentant actuel le plus prolifique parmi les «Celtosceptiques » en France. Voir notamment cette référence au titre évocateur: BRUNAUX, Jean-Louis, Les Celtes. Histoire d'un Mythe. Belin, Paris, 2014.

3. Voir par exemple FALC'HER-POYROUX, Erick, Histoire sociale de la musique irlandaise: Du Dagda au $D A D G A D$, Oxford, New York, Vienne, Peter Lang. Édition Kindle, sous-chapitre «La Musique Celtique ».

4. Voir par exemple ARMAO, Frédéric (ed.), Les Nations Celtiques et le monde contemporain. BabelCivilisations \& Sociétés, Université de Toulon, nVIII, 2013 et notamment FALC'HER-POYROUX, Erick, «L'Interceltisme musical : genèse d'une naissance ", 133-152.

5. Des fanfares, particulièrement bien décrites dans cet article: https:// musicmcrww1.wordpress.com/2016/08/01/street-music-in-manchester-spy-fever-the-firstworld-war-and-the-decline-of-the-peripatetic-professors-of-high-art/

6. HYDE Douglas «The Necessity for De-Anglicizing Ireland» (1892) in O CONAIRE BreandAn (ed.), HYDE Douglas: Language, Lore, and Lyrics, Dublin: Irish Academic press, 1986, p. 167.

7. NICHOLSEN, Michael D. «'File under Celtic': The Uses and Misuses of a Musical Myth, 1882-1999 » in Canadian Journal of Irish Studies, $\mathrm{n}^{\circ} 2,2016$, p. 135-161, 139.

8. Histoire sociale de la musique irlandaise, op. cit., sous-chapitre consacré à Francis O’Neill.

9. Ibid.

10. Michael D. Nicholsen fournit une explication simple et convaincante, à défaut d'être surprenante: «Articles in the Citizen and O'Neill's writing reveal two reasons for using the term 'Celtic Music'. Firstly, musicians and others employed 'Celtic' as synonymous with Irish traditional music and song; simply another way to make the same statement, as demonstrated by the Citizen's coverage of a Chicago St. Patrick's Day celebration in 1885, at which 'Nevin's band...played nothing but Celtic music'. Describing the Irish traditional music as 'Celtic', though, was also a way to distinguish the cultural and racial characteristics of the Irish from the English or British other, to encourage national pride, and to legitimize calls for a politically independent Irish state ». " 'File under Celtic'», op. cit., 139-40.

11. Ibid. 138 et $142-3$. 
12. « To many, perhaps to most people outside the small company of the great scholars, past and present, 'Celtic' of any sort is, nonetheless, a magic bag, into which anything may be put, and out of which almost anything may come. » TOLKIEN, J. R. R. « English and Welsh », inaugural O'Donnell Memorial Lecture at the University of Oxford, 21 octobre 1955, 185-6, in TOLKIEN, J.R.R. \& Christopher (ed.). The Monsters and the Critics, and Other Essays, George Allen \& Unwin, Londres, $1983: 162-197$.

13. https://lescharts.com/showitem.asp?interpret=Alan+Stivell\&titel=Amzer\&cat=a.

14. GRAHAM Stephen, Sounds of the Underground: A Cultural, Political and Aesthetic Mapping of Underground and Fringe Music, Ann Arbor, MI, University of Michigan Press, 2016, p. 23-4.

15. Voir le prélude de l'ouvrage de $M$. Falc'her-Poyroux pour une première définition de ce que l'on appelle musique "traditionnelle ", "musique enracinée produite dans un environnement spécifique " dont la fonction originelle était de "créer de véritables échanges sociaux au sein d'une communauté vivant ensemble toute l'année ». Histoire sociale de la musique irlandaise, op. cit., prélude.

16. http://enyabookofdays.com/articles/wm-tv01.htm.

17. https://www.officialcharts.com/artist/29512/enya/.

18. Voir https://www.imdb.com/title/tt0271900/. «Besides performing some of the soundtrack music and the theme song, Enya also performs two musical numbers during the course of the series: "I Want Tomorrow" and "Aldebaran". The former shows the singer in a very out-ofcharacter context: she plays an evil person with magic powers who goes around blowing up cars by pointing her finger $»$.

19. Enya ne semble d'ailleurs pas une théoricienne de la musique. Elle explique son processus de composition comme suit: «For the signature tune, I was looking for something that was both catchy and original and different to everything else I had written for The Celts. And, um, I had been working with the piano and the synthesizer and it happened on the synthesizer that I got this riff. Um, it went sort of 'bum bum-bum bum-bum,' you know, this type. And I got excited about it and then I started writing the right hand melody. And it just from there on worked for me really. »Ibid.

20. Epona, Bard Dance et the Sun in the Stream.

21. Voir par exemple https://www.lyrics.com/lyric/2067923/Enya/Celts.

22. http://enyabookofdays.com/articles/wm-tv01.htm.

23. La fête irlandaise de Samhain marque effectivement le début de l'année et le début de l'hiver irlandais. Il s'agit de l'ancêtre de la fête d'Halloween. A ce propos, voir par exemple ARMAO, Frédéric, «Fête et Celtisme ou la forge identitaire » in Babel-Civilisations \& Sociétés, $\mathrm{n}^{\circ} \mathrm{VIII}$, op. cit., 203-19.

24. «'Sí an ghealach,/mall san oíche./'Sí an ghrian./Fán liom go Deo./Hoireann is O Hi O Ho ra Ha./'Sí na Samhna,/tús na Bliain Ur./'Sí an crann marbh./Deireadh an tuath./Hoireann is O Ho O Ho ro Ho./Hoireann is O Ho O Ho ro Ho.» Voir par exemple https://www.lyrics.com/lyric/ 2775787/Enya/Deireadh+an+Tuath.

25. Les références sont trop peu précises pour être vraiment pertinentes mais suffisamment éloquentes pour renvoyer, même très vaguement, à la mythologie irlandaise et, peut-être, «faire rêver » l'auditeur.

26. "'File under Celtic' », op. cit., 144.

27. Certains de ses acteurs embrassaient des styles tout à fait inattendus et originaux; on pourrait par exemple mentionner la formation nommée Afro Celt Sound System qui mélange la musique électronique aux influences africaines et aux sonorités dites celtiques et dont l'album Volume 3: Further in Time a atteint la première place des ventes aux Etats-Unis en 2001 (https:// www.billboard.com/music/afrocelts/chart-history/WLP). Voir https://www.youtube.com/ watch?v=2Wmf1xmkuxo\&ab_channel=EarthRitual.

28. https://www.bbc.com/news/entertainment-arts-34614590. 
29. Elle arrive juste derrière U2 en terme de ventes, mais U2 est bien un groupe et non un « solo artist ». https://www.npr.org/templates/story/story.php?storyId=99190609\&t=1611322256797.

30. https://www.independent.ie/entertainment/music/music-news/enya-irelands-wealthiestfemale-performer-despite-not-touring-as-u2-ranked-third-in-music-millionaires-top-50list-34646726.html.

31. https://www.youtube.com/watch?v=nfY9y8LTvJI\&ab_channel=BlackMetalPromotion et https://www.youtube.com/watch?v=lL6NUBk_j6M\&ab_channel=Bathory

32. Par exemple https://www.youtube.com/watch? v=cAEnwxw9wMM\&ab_channel=AllThingsProg

33. https://archive.vn/20120805010403/http://www.lordsofmetal.nl/showinterview.php? $\mathrm{id}=1544$ \&lang=en.

34. https://web.archive.org/web/20120210150222/http://www.rock-impressions.com/ cruachan_inter1e.htm. Cette influence fut confirmée en 2004 : « Another major influence was an Irish rock band from the '70's called The Horslips that mixed rock with traditional Irish music. Other bands that influenced us at the time (late ' 80 's early ' 90 's) were Bathory with the Viking style Quorthon created, Isengard and possibly Storm. They are the only other Folk-like bands that I remember from that era, even keyboards were only really being introduced large scale into songs, especially in the Black metal scene. (...). It's crazy to see how the Folk metal scene has grown from just one or two bands ». Ibid.

35. «Paganism is a very personal religion and a lot of people have their own interpretation of beliefs. I will not go into detail about my beliefs because I treat them as very personal. As I grow older I realise that when you are serious about a religion, you do not exploit your beliefs like so many childish black metal bands who only sing about sat*n because it is trendy, if they were true believers they would know different. Anyway, I don 't want to get into that, each to their own etc. » https://web.archive.org/web/20120210150222/http://www.rock-impressions.com/ cruachan_inter1e.htm.

36. Les mêmes, donc, que ceux mentionnés précédemment en relation avec le Rock celtique, voir supra.

37. MAYER Adam \& TIMBERLAKE Jeffrey M., "'The Fist in the Face of God': Heavy Metal Music and Decentralized Cultural Diffusion » in Sociological Perspectives, Vol. 57, No. 1 (printemps 2014), Sage Publications, Inc., 27-51, p. 28.

38. https://web.archive.org/web/20120210150222/http://www.rock-impressions.com/ cruachan_inter1e.htm.

39. https://archive.vn/20120805010403/http://www.lordsofmetal.nl/showinterview.php? id=1544\&lang=en.

40. Pour une première approche, voir MACKILLOP, James, Dictionary of Celtic Mythology, Oxford, Oxford University Press, 1998, 113-4.

41. La Morrigán est l'une des divinités les plus célèbres du panthéon celtique irlandais.

42. A titre d'exemples, « The First Battle of Moytura », "Cúchulainn », " Táin Bó Cuailgne », « To Moytura We Return », " A Celtic Mourning », «Celtica (Voice of the Morrigan) », " A Druid's Passing ", " The Children of Lire ", " The Gael », " Diarmuid and Grainne », " The Arrival of the Fir Bolg ", etc.

43. L'analyse détaillée et exhaustive des paroles de Cruachan sort du cadre strict de cette étude. A titre d'exemple, on pourra par exemple consulter les paroles du morceau "Cuchulainn» (https://www.musixmatch.com/lyrics/Cruachan/Cuculainn) et les mettre en parallèle avec les divers épisodes mythologiques mettant en scène le héros irlandais (REF). En 2004, Fay exprimait déjà le souhait de créer un album entier dédié au héros et, probablement sans le vouloir, donne réellement l'impression de chercher à s'inscrire dans la tradition des passeurs de mythes irlandais : "I've thought about doing a concept album, although it would more than likely have to be spread out over two albums, about Cuchulainn or more exactly about The Tain where he 
solely defends his homeland against a full army. I'd like the layout of the booklet to be done in such a way that it looks like an old manuscript with the full story of the Tain inside with the lyrics, so people will get the impression that they are actually reading old texts. I'd like to do it in a way that it's like a soundtrack and has big bombastic sounds and some narrative along with the songs. It's only a pipe dream at the moment but if the label or any label is willing to fund it we will be more than happy to do it ". https://web.archive.org/web/20080304065301/http:// www.getreadytorock.com:80/pure_metal/cruachan.htm.

44. "We hope that we will inspire our fans to learn about the history in their own country. ", cité supra.

45. "Like most people in the world we are very proud of our nationality. ", https:// web.archive.org/web/20120210150222/http://www.rock-impressions.com/

cruachan_inter1e.htm.

46. Un interviewer italien demande : «I've read that there were a lot of connections between nazis and celtic culture and the celtic cross is used by the right youngs as a symbol. Your celtic interest has something to do with this politic attitude?". La réponse apportée est claire: "NOOOOOO!!!!, We do not support this attitude at all, yes the nazis adopted very famous symbols, the swastika was from the roman army many years ago (as far as I know) and the celtic cross is a very famous symbol in Ireland. The nazis distorted them for ever but Ireland still uses the celtic cross, in catholic churches, grave stones etc. I think the swastika will always remain destroyed however ", ibid.

47. https://web.archive.org/web/20080304065301/http://www.getreadytorock.com:80/ pure_metal/cruachan.htm.

48. Nous préférons donner ici l'intégralité de la réponse de Fay : «On FolkLore there is a song called Bloody Sunday, the lyrics tell of a horrific event in very recent Irish history where British soldiers shot and killed innocent, un-armed and peaceful protestors in Northern Ireland. The actual background is explained in our lyric sheet but I felt that in today's climate, with what has happened on September 11th, that people should know that it is not terrorists from thousand[s] of miles away that commit horrible murders, it can also be the armed forces of your closest neighbour. I hear on the news about the uncivilised Talibaan [sic], I wonder what the people of England think about their army killing innocent people in their name. Anyway, this atrocity was covered up in the 1970's but is currently under investigation again and hopefully the truth will be told to the world, will the British government apologise? Will an apology be enough? We will see ", ibid. Les excuses viendront en juin 2010, de la bouche même de David Cameron et au sein de la Chambre des Communes.

49. Une référence directe au slogan de l'IRA « Tiocfaidh ár lá » (our day will come). https:// www.allthelyrics.com/lyrics/cruachan/bloody_sunday-lyrics-534227.html.

50. Michael Collins est une figure emblématique de l'indépendance irlandaise : révolutionnaire et homme politique de premier plan, il fut tué au cours d'une embuscade dans des circonstances troubles qui n'ont fait que renforcer l'aura du personnage et son inscription dans l'imaginaire nationaliste irlandais.

51. Cette approche ne fait d'ailleurs aucun doute : «A step towards independence / Is better that [sic] a war we cannot win ", extrait des paroles de «Michael Collins". https:// www.allthelyrics.com/lyrics/cruachan/michael_collins-lyrics-534236.html.

52. « De Valera, our elected president / Knew a republic he would not get / He sent Collins to meet the British / He sent him to his death! ». Ibid.

53. «But Michael would return to lead us/ In our fight to re-claim our lands / The IRB will march victorious / For they shall have the upper hand » ou, plus loin, "In reprisal the British army killed / Innocent people watching a hurling game / That day would become a turning point / Irish psyche would never be the same ». Ibid. 
54. Notamment le Black Metal. Cruachan est considéré par beaucoup comme un groupe de Black metal à part entière : "We actually considered ourselves as a Pagan metal band as we didn't sing about Satan or all that stuff but obviously it was easier for people to lump us in as a Black metal band ». https://web.archive.org/web/20080304065301/http://www.getreadytorock.com:80/ pure_metal/cruachan.htm.

55. Fay précise que ce sont bien toutes les religions qui sont visées par ses propos : «I know I'm having a go at the Catholic church in this song but it's meant to encompass all organised religions from Judeo-Christian religions to the Islamic religion », ibid.

56. Etonnement, Fay se démarque parfois de l'antichristianisme aveugle et déplore un manque de spiritualité en Irlande : «Very few people go to church now in Ireland, which to be very honest, I think is sad. Ok, I am not a Christian but I would prefer that people believe in something rather than nothing and modern Christianity is not as bad as it was hundreds of years ago ", https:// web.archive.org/web/20120210150222/http://www.rock-impressions.com/

cruachan_inter1e.htm.

57. https://genius.com/Cruachan-pagan-lyrics.

58. " [Money is] basically our Achilles heel...too much stuff to do and not enough time or money to do it. " https://web.archive.org/web/20080304065301/http://www.getreadytorock.com:80/ pure_metal/cruachan.htm.

59. " we're all self-taught in the band. We wouldn't have time to study music as we all have day jobs to keep our heads above water, so to speak ». https://web.archive.org/web/ 20080304065301/http://www.getreadytorock.com:80/pure_metal/cruachan.htm.

60. Ibid.

61. «When we left Karmageddon, we were happy to leave them. I mean, nice bunch of guys, I liked them, but we have never received a penny in royalties. We sold thousands and thousands of CDs around the world, but we did not received a penny and it was definitely not working out. They gave us a reduced budget to record 'Pagan', compared to 'Folk-Lore', so that was totally negative " ", https://archive.vn/20120805010403/http://www.lordsofmetal.nl/ showinterview.php?id=1544\&lang=en.

62. «When it was finished, the invoice was sent to Black Lotus from the studio, twelve thousand euro, the rest of the recording fee. Two months later they still had not heard anything from Black Lotus, they were constantly contacting them. I was all the time on the phone too and apologized and apologized and I eventually got to the stage when I personally being threatened with court, to be taken to court. I was told "You better find a lawyer, because we are taking you to court". In the week I was told that, I got a call from Black Lotus, saying that they were closing the doors. They did not say the word "bankrupt", but eventually it looked like they were bankrupt. Twelve thousand euro and I had to come up with it... », ibid.

63. Ibid.

64. Les différences opposant les deux pans de ce mouvement général du Renouveau Celtique n'étaient en fait pas si franches; le Gaelic Revival d'une part et l'Irish Literary Revival de l'autre étaient probablement plus perméables qu'il n'y parait, même si le présent article n'entend pas approfondir cette question. 


\section{RÉSUMÉS}

Le terme « celtique » est décliné à l'envi dans tout un panel de productions culturelles modernes et contemporaines, notamment en Irlande, au point que le terme soit pratiquement devenu synonyme d'«irlandais» lorsque celui-ci est envisagé en opposition au «non-celte»comprendre, en l'occurrence, l'Anglais. Le présent article s'interroge sur l'origine d'un tel recyclage identitaire et analyse deux exemples de productions culturelles issues de la scène irlandaise contemporaine : l'artiste Enya et le groupe de Celtic Metal Cruachan sont deux acteurs majeurs de leurs écosystèmes respectifs, que l'on qualifiera respectivement de « mainstream » et d'« underground». Nous nous attarderons sur les caractéristiques opposant ou unissant ces deux formations musicales et nous interrogerons sur la place qu'elles occupent sur la scène artistique irlandaise mais aussi, plus largement, dans la culture et l'histoire récente du pays.

\section{INDEX}

Mots-clés : mythes nationaux, identité, Celtes, musique populaire, Metal studies

\section{AUTEUR}

\section{FRÉDÉRIC ARMAO}

Université de Toulon, Laboratoire Babel EA 2649

Frédéric Armao est Maître de Conférences-HDR à l'Université de Toulon. Il se spécialise dans l'étude du monde dit celtique, depuis les mythes anciens jusqu'au recyclage identitaire moderne et contemporain de la notion de Celtes. Son ouvrage Uisneach or the Center of Ireland, préfacé par Michael D. Higgins, président de l'Irlande, est en cours de publication chez Routledge. 